\title{
EFFECT OF AN UNDERDEVELOPED HIGH VALUE-ADDED SECTOR ON THE LOW VALUE-ADDED SECTOR IN LESS DEVELOPED COUNTRIES
}

\author{
Sandris Ancans' Mg.oec.
Latvia University of Life Sciences and Technologies
}

\begin{abstract}
Average nominal earnings among world countries are very diverse, even within the EU. The disparity between Luxembourg and Bulgaria is almost ten times, as the East European EU Member States considerably lag behind in terms of production of high value-added products. It is important for the East European EU Member States to reduce the disparities, which could be achieved through raising labour productivity, mainly in the tradable sector. The research aim is to identify the effect of an underdeveloped high value-added sector on the low value-added sector in less developed countries. An analysis of empirical data supported the hypothesis that an underdeveloped high value-added tradable subsector in less developed countries does not allow reaching the labour productivity level of developed economies in the low value-added tradable subsector because of the availability of a relatively cheaper labour force that does not force businesses to raise their labour productivity levels.
\end{abstract}

Key words: labour productivity, earnings level, tradable sector, high value-added sector, low value-added sector.

JEL code: FOO

\section{Introduction}

The nominal earnings disparities among the EU Member States were significant, reaching almost ten times: in 2014, the highest mean earnings in industry, construction and services (in companies with 10 employees or more) were reported in Luxembourg with EUR 4026, while in Bulgaria the earnings were the lowest at EUR 431, which should be a concern for policy makers as well. The nominal earnings were lower in almost all the East European EU Member States (former communist countries) than in the West European EU Member States. The only exception was Slovenia with EUR 1582, surpassing only one West European EU Member State - Portugal. The minimum wage is also a relatively good indicator that shows the disparities in the standard of living within the EU, where the highest minimum wage was set in Luxembourg with EUR 1921, whereas the lowest was in Bulgaria with EUR 174. In terms of minimum wages, Slovenia surpassed three West European EU Member States: Portugal, Spain and Malta (Eurostat). Therefore, the purpose of the present research is to contribute to the understanding of factors that hinder the reduction of nominal income disparities within the EU, mainly between the West European and East European EU Member States.

The large nominal earnings disparities among the EU Member States make it necessary for the East European EU Member States to increase labour productivity in their tradable sectors, which allows raising labour force earnings both in the tradable sector and in the entire economy, thereby contributing to income convergence among the EU Member States or at least a decrease in the significant income disparities.

The research aim is to identify the effect of an underdeveloped high value-added sector on the low value-added sector in less developed countries.

The specific research tasks were set as follows: 1) to characterise the roles of high and low value-added sectors and of the tradable sector in a modern economy; 2) to identify the effect of a high value-added tradable subsector on labour productivity in the low value-added tradable subsector. 
The research employed Eurostat data and other sources of information. The research used the following methods: correlation analysis, single-factor analysis of variance (ANOVA), analysis and synthesis, logical construction.

The research put forward the following hypothesis: an underdeveloped high value-added tradable subsector in less developed countries does not allow reaching the labour productivity level of developed countries in the low value-added tradable subsector because of the availability of a relatively cheaper labour force in the less developed countries.

\section{Research results and discussion}

\section{Roles of high and low value-added sectors and of the tradable sector}

Nowadays scientists discuss such issues as high and low value added, high and low value-added goods and services, as well labour productivity and an income level determined by it. There are distinguished high and low value-added industries and even sectors. From the perspective of foreign trade, there are also distinguished the tradable sector and the nontradable sector. It has to be noted that according to the Balassa-Samuelson theory, the nontradable sector is more labour intensive and, consequently, no considerable labour productivity differences exist among nontradable sector industries and across countries, and these differences do not determine the nominal earnings level in the entire economy (Krugman P.R., Obstfield, M, 1994); therefore, the mentioned differences were not analysed in the present research. All the above-mentioned factors determine the nominal as well as the real income level in any open economy. Since nominal income levels are very diverse not only among world countries but also among EU Member States, it is necessary to perform an in-depth examination of the roles of the above-mentioned sectors and their interaction.

The nominal income level in any open economy is determined by labour productivity in the tradable (export) sector, as stated by the Balassa-Samuelson theory. Yet it is very important what value added the exports have - whether the exports are of high or low value-added. Less developed countries export mostly low value-added goods and services, whereas developed countries export both low and high value-added products.

For simplicity, let us assume that there are only two subsectors in the tradable sector: a high value-added subsector and a low value-added subsector. In reality, the division is broader and more gradual. Within the present paper, industries or kinds of economic activity requiring a highlyqualified labour force and high technologies to produce high value-added goods or services are attributed to the high value-added tradable subsector. In contrast, the low value-added tradable subsector is comprised of the industries or kinds of economic activity requiring a less-qualified labour force and different-level technologies to produce low value-added goods or services. For example, to produce complicated manufacturing goods, modern electronics, equipment etc. that have high value-added, it is necessary to have and employ a highly-qualified labour force and high technologies and to cooperate with institutions dealing with science and technology, research and development and innovation. Conversely, producing agricultural and other low value-added goods requires a less-qualified labour force, while technologies (agricultural machines and equipment) could be complicated and expensive. In the last half a century, for example, very rapid changes occurred in the electronics industry and completely new goods emerged, which is incomparable with the agricultural industry where changes occurred at a much slower pace agricultural commodities have little changed during the centuries (only new crop varieties were 
developed), while technologies used in agriculture (e.g. precision farming) developed as fast as technologies in general.

In the world, there are quite many high-income countries, both large and small in terms of population. In these countries, the high income levels are determined by the factors related to exports (tradable sector).

In world countries, high incomes are generated in three main ways. Two of them are specific to small countries in terms of population: 1) exports of low value-added commodities; 2) exports of low value-added services. As regards the first way, there is a number of Arab and other countries endowed with relatively large oil or other resources. The second way is attributed to small the socalled offshore countries that sell (and export) a lot of financial services, given the small populations of these countries, ranging from tens of thousands to a few millions. The third way involves the production and, of course, export of high value-added goods and services, which is characteristic of the developed countries with large populations.

\section{Effect of the high value-added tradable subsector on labour productivity in the low value-added tradable subsector}

The Eurostat database provides data on earnings in the business economy that encompasses the following sectors according to the NACE Rev.2 classification: industry (sections B to E), construction (section $\mathrm{F}$ ) and services (sections $\mathrm{G}$ to $\mathrm{N}$, excluding activities of holding companies K64.2). The sections included in the business economy mainly correspond to tradable sector industries. Industry produces mostly tradable goods, construction services may be considered to be internationally tradable services within the EU, as there is free movement of services in this free trade bloc. Other service sections (G-N) include wholesale and retail trade (G), accommodation (I), transportation and storage $(\mathrm{H})$, information and communication $(\mathrm{J})$, financial and insurance activities (K), real estate activities (L), professional, scientific and technical activities (M) and administrative and support service activities $(\mathrm{N})$, which also involve mainly internationally tradable activities. The remaining service sections $(\mathrm{O}-\mathrm{U})$, which are not included in the business economy, relate to the nontradable sector, with a few exceptions. In view of the fact that Eurostat does not provide data broken down by the tradable and nontradable sectors, the data on the business economy best reflect the tradable sector.

Beside the business economy (tradable sector) as a whole, the author selected the following industries of this sector: manufacturing as a whole, which is usually the key contributor to exports, high technology manufacturing, low technology manufacturing, manufacture of food products as well as two service industries: accommodation and information and communication technology (ICT), which are strongly associated with exports or the tradable sector. Accommodation is directly related to tourism, which is an export service. Since no complete data on the tourism industry are available in the Eurostat database, the author chose the accommodation industry for analysis. High value-added could be attributed to high technology manufacturing as well as ICT services. The other three industries, except manufacturing as a whole, are considered to represent low valueadded industries.

The countries available in the Eurostat database, which were mostly EU Member States, as well as Switzerland and Norway, were selected for analysis. Since the available data were collected according to the same methodology, the data were comparable and allowed drawing relevant conclusions. Table 1 shows countries ranked by mean earnings in companies with 10 or more 
employees, as the data on the mean earnings in all companies are not available for all the selected countries. In addition, a correlation between mean earnings and labour productivity in the tradable sector (business economy) and individual industries of this sector was calculated as well.

As shown in Table 1, the correlation calculation results indicate a strong empirical relationship (correlation coefficients are high, in the range of 0.72-0.97) between the average earnings and the labour productivity both in the business economy, i.e. the tradable sector and in the individual tradable sector industries.

Correlation between average earnings (EUR) and apparent labour productivity (thou. EUR) in selected tradable sector industries in selected European countries in 2014

\begin{tabular}{|c|c|c|c|c|c|c|c|c|}
\hline \multirow[b]{2}{*}{ Country } & \multirow[b]{2}{*}{$\begin{array}{l}\text { Average } \\
\text { earnings }\end{array}$} & \multicolumn{7}{|c|}{ Productivity in: } \\
\hline & & $\begin{array}{l}\text { business } \\
\text { economy }\end{array}$ & $\begin{array}{l}\text { Manufac- } \\
\text { turing }\end{array}$ & $\begin{array}{l}\text { high- } \\
\text { tech }\end{array}$ & $\begin{array}{l}\text { low- } \\
\text { tech }\end{array}$ & food & $\begin{array}{c}\text { ICT } \\
\text { ser- } \\
\text { vices }\end{array}$ & $\begin{array}{l}\text { Accom- } \\
\text { modation }\end{array}$ \\
\hline Switzerland & 6011 & 113.0 & 131.4 & 216.2 & 93.8 & n.d. & 171.6 & 55.4 \\
\hline Norway & 5031 & 131.3 & 103.6 & $155.8^{*}$ & 83.5 & 88.9 & 141.0 & 43.8 \\
\hline Luxembourg & 4206 & 86.8 & 75.8 & n.d. & 63.7 & 44.2 & 213.5 & 48.3 \\
\hline Denmark & 4194 & 77.8 & 82.5 & 145.9 & $72.5^{*}$ & 66.3 & 91.0 & 48.1 \\
\hline Ireland & 3778 & 94.8 & 194.1 & $442.7 *$ & n.d. & 184.1 & $206.3 *$ & 26.7 \\
\hline Sweden & 3578 & 70.3 & 83.2 & 162.0 & 74.7 & 60.5 & 98.8 & 38.2 \\
\hline Finland & 3232 & 59.2 & 70.8 & 85.6 & 71.3 & 59.7 & 96.0 & 34.4 \\
\hline Belgium & 3216 & 71.0 & 98.9 & 204.8 & 73.9 & 73.5 & 115.0 & 48.6 \\
\hline UK & 3151 & 65.6 & 76.1 & 90.5 & 65.1 & 67.3 & $126.0 *$ & 38.9 \\
\hline Germany & 3045 & 55.1 & 71.5 & 97.3 & 48.0 & 39.9 & 102.0 & 24.0 \\
\hline Netherlands & 2988 & 59.1 & 87.1 & 123.8 & 76.4 & 80.2 & 101.6* & 33.4 \\
\hline Austria & 2806 & 62.4 & 79.3 & 111.2 & 62.4 & 52.6 & 90.0 & 38.0 \\
\hline France & 2775 & 57.1 & 66.7 & 97.9 & 55.1 & 53.0 & 88.8 & 44.6 \\
\hline Italy & 2458 & 45.4 & 55.8 & 90.3 & 46.6 & 50.8 & 82.7 & 36.9 \\
\hline Spain & 1985 & 40.4 & 56.6 & 97.1 & 46.6 & 50.8 & 75.9 & 37.2 \\
\hline Cyprus & 1840 & 33.4 & 29.8 & $46.0 *$ & 25.9 & 27.4 & 88.2 & 29.8 \\
\hline Malta & 1720 & 33.1 & n.d. & $30.2 *$ & 30.6 & n.d. & n.d. & 25.9 \\
\hline Slovenia & 1582 & 32.1 & 36.5 & 77.9 & 27.0 & 27.5 & 52.1 & 23.2 \\
\hline Greece & 1562 & 22.8 & 35.2 & 54.9 & 29.7 & 34.6 & 49.4 & 29.5 \\
\hline Portugal & 1249 & 23.9 & 26.8 & 45.0 & 22.2 & 22.5 & 58.0 & 22.6 \\
\hline Estonia & 1066 & 25.7 & 24.7 & 27.5 & 21.9 & 23.2 & 41.7 & 15.2 \\
\hline Croatia & 1057 & 20.4 & 18.2 & 43.4 & $15.1^{*}$ & 16.2 & 43.2 & 27.1 \\
\hline Poland & 980 & 21.5 & 23.8 & 30.4 & 19.4 & 21.0 & 37.2 & 15.6 \\
\hline Slovakia & 930 & 21.5 & 25.0 & $35.6 *$ & $16.4^{*}$ & 17.7 & 46.3 & 10.4 \\
\hline Czechia & 925 & 23.9 & 27.3 & 32.9 & 19.2 & 18.7 & 46.0 & 16.0 \\
\hline Hungary & 811 & 20.7 & 29.3 & $48.3 *$ & 16.2 & 17.8 & 33.5 & 14.1 \\
\hline Latvia & 806 & 16.3 & 16.1 & 37.0 & 14.3 & 13.8 & 28.8 & 11.7 \\
\hline Lithuania & 706 & 16.0 & 15.8 & 32.7 & 13.8 & 14.7 & 30.0 & 9.0 \\
\hline Romania & 521 & 14.6 & 13.4 & 19.9 & 9.4 & 9.8 & 28.0 & 10.0 \\
\hline Bulgaria & 431 & 10.5 & 9.9 & 18.2 & 7.6 & 8.7 & 25.3 & 7.7 \\
\hline $\begin{array}{r}\text { Coefficient } \\
\text { betw } \\
\text { earnings and }\end{array}$ & $\begin{array}{l}\text { orrelation } \\
\text { n average } \\
\text { oductivity }\end{array}$ & 0.97 & 0.85 & 0.72 & 0.95 & 0.75 & 0.87 & 0.88 \\
\hline
\end{tabular}

Source: author's calculations based on Eurostat 
An analysis of variance showed that the $p$-value was smaller than the significance level of 0.01 (author's calculations). This is not a startling fact because according to the Balassa-Samuelson theory (Krugman P.R., Obstfield, M, 1994), labour productivity in the tradable sector determines the overall earnings level in the whole economy, especially in today's globalised world and particularly among the EU Member States with free movement of goods and services, including Switzerland and Norway that have almost free trade with the EU. The highest correlation (0.97) existed between the average earnings and the labour productivity in the business economy (tradable sector as a whole). A slightly lower correlation was identified in the individual tradable sector industries. In the author's opinion, it would be a very positive phenomenon if no strong correlation existed between average earnings and labour productivity in low value-added tradable subsector industries.

If there were no strong correlation between average earnings and labour productivity in any low value-added tradable subsector industry in lower income (economic development level) countries, i.e. if the availability of a relatively cheaper labour force made no effect on the labour productivity in the entire tradable sector and, first of all, in this sector's low value-added industries, this would allow raising the labour productivity in the low value-added tradable subsector industries of these countries, i.e. in the industries which exist in these countries and the proportion of which in their economies is significant. Consequently, earnings would rise in the whole economy, including in nontradable sector industries, even though no high value-added tradable sector industries exist in these countries or their proportion in the economy is insignificant. For example, even though East European countries actually have no high-technology manufacturing or its proportion in their economies is very low, these countries could achieve the labour productivity level of developed countries in such industries as low-technology manufacturing, manufacture of food products, accommodation and other low value-added tradable sector industries. Nominal incomes would converge, to some extent, between the developed West European and the less developed East European countries. However, the empirical data do not indicate such a phenomenon; there are only a few exceptions.

This is most apparent in the accommodation industry if comparing Croatia with such countries as Germany and Ireland. In 2014, average earnings in Croatia were only just above EUR 1000, while in Germany they were more than EUR 3000 (about three times higher) and in Ireland they were EUR 3800 (almost four times higher). Labour productivity in this industry in Croatia was EUR 27.1 thou., while in Germany and Ireland it was EUR 24.0 and 26.7 thou., respectively, i.e. slightly lower. This phenomenon could be explained by economies of scale, including labour economies of scale, as the travel and tourism industry, which is closely associated with accommodation, in Croatia was relatively larger (total contribution of travel \& tourism to GDP was $25 \%)$ than that in Germany (11\%) and Ireland (6\%). A similar situation was in Slovenia where labour productivity in its accommodation industry was only slightly lower than that in Germany and Ireland. In Slovenia, too, the travel and tourism industry made a relatively large total contribution to its GDP ( $13 \%$ of GDP). In Greece, where average earnings were approximately two times lower than those in Germany and Ireland, labour productivity was higher at EUR 29.5 thou. In Greece, too, travel and tourism ( $20 \%$ of GDP) and related accommodation was a very significant export industry. In terms of labour productivity in the accommodation industry, Germany and Ireland considerably differed from most of the developed West European countries where it was significantly higher. This could be explained by the use of a relatively cheap foreign labour force, 
mainly from Eastern Europe, in these high-income countries, which did not motivate businesses in these countries to raise their labour productivity through optimising the number of their employees.

The analysis of labour productivity in manufacturing shows that there was only one country Cyprus - where this indicator was lower than it was supposed to be. In the period 2008-2014, the labour productivity decreased by approximately $12 \%$ (author's calculations based on Eurostat), which was affected by the global financial and economic crisis.

In high technology manufacturing, there was only one exception - Hungary - in which labour productivity in this industry was higher than in three countries with higher average earnings Malta, Portugal and Cyprus. Slovenia, too, outperformed such countries as Cyprus and Malta. As regards low technology manufacturing, it is worth mentioning Cyprus where labour productivity in this industry was relatively low.

Labour productivity in the food industry of Slovenia and Malta was lower than that in Greece, while Portugal outperformed Greece and Slovenia in the industry of ICT services.

As regards the business economy as a whole, labour productivity only in Estonia was slightly higher than in Greece where average earnings were approximately 1.5 times higher. A quite strong trend was observed - labour productivity in the business economy in all the analysed countries rose from year to year. An exception was Greece, which was a heavily indebted country and in which its GDP significantly contracted (by about $25 \%$ ), as well as Cyprus that underwent a banking crisis in 2013 and in which its GDP also considerably decreased (by approximately $15 \%$ ), which obviously negatively affected the labour productivity in these countries in their entire business economies (tradable sectors).

Labour productivity in several analysed industries in Ireland was untypically high, compared with even the other developed countries, yet the purpose of this research was not to identify the causes of it.

The above-mentioned data indicate that the high value-added tradable subsector (the existence or lack of it) significantly affects the low value-added tradable subsector through such a factor of production as labour and remuneration paid to it. There is a marked economic phenomenon that can be observed in lower income countries - the availability of a relatively cheap labour force, which is one of the four factors of production and one of the most important factors of production, does not motivate, encourage and force businesses operating in the tradable sector's low valueadded subsector raise labour productivity and approach the level reported in developed countries. Conversely, in high income countries, the labour force is expensive, which motivates, encourages and forces the businesses of these countries that are engaged in the tradable sector's low valueadded subsector to raise their labour productivity in order to remain completive in terms of pay with the high value-added subsector. In high-income countries, average earnings in low valueadded industries are not as high as in high value-added industries, yet the earnings are adequate to the income level in these countries or are significantly higher than in corresponding industries in lower income countries.

Figure 1 shows a scatterplot for the empirical linear relationship - average earnings (independent variable) are strongly positively related to labour productivity (dependent variable) in the business economy (tradable sector) - for all the countries presented in Table 1. 




Fig. 1. Empirical relationship between average earnings and labour productivity in the business economy (tradable sector)

This indicates a serious problem in lower income countries - the proportion of the high valueadded tradable subsector is low, which cannot raise the overall earnings level in the entire economy. For this reason, the labour force in such economies is relatively inexpensive, which, on the one hand, is an advantage for businesses that need to hire employees at a lower cost. On the other hand, the availability of a relatively inexpensive labour force is a serious disadvantage, as it allows businesses to hire and employ a larger number of employees and not to tackle problems related to technological advancement and, consequently, the release of redundant employees or an increase in output, while employing the same number of employees. The freed up labour force could be engaged in other industries, which would contribute to economic growth at the current number of the labour force or even at a declining population as well as a decreasing number of the labour force, which is a typical trend observed in Latvia and other East European EU Member States for a long period.

As regards labour productivity in high value-added industries in less developed countries, it is relatively low and, as mentioned above, also strongly correlated with average earnings in the entire economy. In less developed countries, the availability of a relatively cheap labour force does not allow achieving a high labour productivity level in neither the low value-added tradable subsector that is significantly represented nor the high value-added tradable subsector that is insignificantly represented in their economies.

The availability of a relatively inexpensive labour force, in the opinion of the author, relates to the so-called middle-income trap problem, i.e. the countries, upon reaching a middle income level, cannot transit to a new, higher income level that approaches the income level of developed countries or shift to the innovation-based stage (World Bank, s.a.). The cause is the fact that there is no driver - a high value-added tradable subsector and its integral component - a highly qualified labour force and innovation that lead to higher labour productivity, higher labour incomes and more tax revenue paid to the government. As regards innovation and creativity, problems with so necessary prerequisites are particularly characteristic of post-communist countries where the 
creativity and the initiative were supressed for half of a century. Even though almost three decades passed after communism disappeared in Eastern Europe, the consequences of it still remain in the way of thinking of the entire society, which affects and will affect entrepreneurship for some time.

\section{Conclusions, proposals, recommendations}

1) Nominal income (earnings) disparities among the EU member States are very significant, reaching almost ten times, which makes it necessary for policy makers to focus on this problem not only at the EU but also at the national level.

2) There is a quite strong empirical relationship in the analysed EU countries between average earnings and labour productivity in the entire tradable sector (business economy) as well as in individual industries of the sector, besides, in both high and low value-added industries, which indicates a theoretical possibility for lower income countries to reach the labour productivity level of developed countries in their low value-added industries.

3) The hypothesis mainly proved to be true - the high value-added tradable subsector considerably affects the low value-added tradable subsector. The insignificant high value-added tradable subsectors of post- communist EU Member States are not able to raise the earnings level in their entire economies; for this reason, a relatively inexpensive labour force is available in the mentioned countries, which does not motivate, encourage and force businesses engaged in low value-added tradable subsector to raise their labour productivity.

4) In high-income countries with large populations, the proportion of the high value-added tradable subsector is significant, which raises the overall earnings level in the entire economy. The labour force is expensive, which, in its turn, forces businesses to increase their labour productivity also in the low value-added tradable subsector in order not to lose their competitiveness in terms of pay. Conversely, in low income countries the proportion of the high value-added tradable subsector in the economy is low, which does not raise the earnings level in the entire economy. The labour force is inexpensive, and this factor does not force businesses engaged in the low value-added tradable subsector to raise their labour productivity. The businesses would be forced to do it if the high value-added tradable subsector considerably expanded in a low-income country.

5) If the East European EU Member States do not develop their high value-added tradable subsectors, a considerable increase in the nominal earnings level in the entire economy is not possible.

\section{Bibliography}

1. Country reports. (2017). World Travel and Tourism Council. Retrieved: https://www.wttc.org/research/economic-research/economic-impact-analysis/country-reports/\#undefined. Access: 16.11.2017.

2. Eurostat (2017). Apparent labour productivity. Retrieved: http://ec.europa.eu/eurostat/tgm/refreshTableAction.do?tab =table\&plugin $=1 \& p c o d e=t i n 00152 \& l a n g u a g e=e$ n. Access: 25.09.2017.

3. Eurostat (2017). Mean monthly earnings by sex, age and occupation - NACE Rev. 2, B-S excluding O. Retrieved: http://appsso.eurostat.ec.europa.eu/nui/show.do?dataset=earn_ses14_21\&lang=en Access: 25.09.2017.

4. Krugman, P.R., Obstfield, M. (1994). International Economics. Theory \& Policy. 3-rd edition.

5. World Bank (2017). Governance and the Law. World Development Report 2017. Retrieved: http://www.worldbank.org/en/publication/wdr2017. Access: 16.10.2017. 